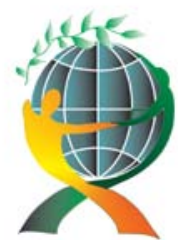

\author{
(online) = ISSN $2285-3642$ \\ ISSN-L = $2285-3642$ \\ Journal of Economic Development, Environment and People \\ Volume 9 , Issue 3, 2020 \\ URL: http://jedep.spiruharet.ro \\ e-mail: office jedep@spiruharet.ro
}

\title{
Effect of Climate Change on Agricultural Output in Ethiopia
}

\author{
Adamu Mulu Ketema* ${ }^{1}$, Kasahun Dubale Negeso ${ }^{2}$ \\ ${ }^{1}$ Salale University, Ethiopia \\ ${ }^{2}$ Adama Science and Technology University)
}

\begin{abstract}
Currently, climate change is known as the major environmental problem the world face. Its effect is openly reduced agricultural output in particular and economic growth in general. The study aimed to examine the long run and short-run effect of climate change on agricultural output in Ethiopia throughout 1980-2016. The ARDL approach to cointegration was applied to examine the long run and short-run effect of climate change on agricultural output. ADF test was used for the Unit root test. The finding of the bound test shows that there is a stable long-run relationship between RAGDP, labour force, Mean annual rainfall, Average temperature, agriculture land, and fertilizer input import. The estimated long-run model reveals that climate changes have an important effect on the agricultural output which is the main contributor of the overall GDP of the country. The coefficient of the error correction term is -0.738 suggesting about $73.8 \%$ percent annual adjustment towards long-run equilibrium. The estimated coefficients of the short-run show that mean annual rainfall have a significant effect but the average temperature is an insignificant effect on output. In the long run, both main variables of interest have a significant effect on agricultural output with a positive effect from mean annual rainfall and negative effect from average temperature. To reduce the effect of climate change the study recommends government and stakeholders need to create specific policies to reduce the effect of climate change especially focus on technological innovation that averts the effect of an increase in temperature that would increase the output and adopting technology at macro and micro level.
\end{abstract}

Keywords: Ethiopia, ARDL method of co integration, agricultural output, climate variable

JEL Codes: Q1, Q10, R15,

How to cite: Ketema, A.M., Negeso, K.D.(2020)- Effect of Climate Change on Agricultural Output in Ethiopia, Journal of Economic Development, Environment and People, 9(3), p 6-21, DOI: https://doi.org/10.26458/jedep.v9i3.665

\footnotetext{
* Corresponding author E-mail address: adamumulu6@gmail.com
} 


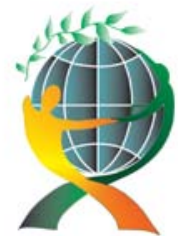

\author{
(online) = ISSN $2285-3642$ \\ ISSN-L = $2285-3642$ \\ Journal of Economic Development, Environment and People \\ Volume 9 , Issue 3, 2020 \\ URL: http://jedep.spiruharet.ro \\ e-mail: office jedep@spiruharet.ro
}

\title{
1. INTRODUCTION
}

Currently, change in the climate of the world is widely agreed upon by the scientific community. The Intergovernmental Panel on Climate Change (IPCC) has concluded that human activities are altering our climate system and will continue to do so (IPCC, 2014). In the previous century, surface temperatures, associated impacts on physical and biological systems are progressively being observed. Science tells us that climate change will bring about gradual changes, such as sea-level rise, and shifts of climatic zones due to increased temperatures and changes in precipitation patterns.

Globally Changes in atmospheric concentrations of greenhouse gases (GHGs) and aerosols, land cover, and solar radiation alter the energy balance of the climate system. GHGs emissions are increased over time due to human activities. Economic and population growth are most drivers of the increase in Carbon dioxide (IPCC, 2014). More than 75\% of all Co2 emission comes from developed countries. Recently there is accelerating emission GHGs in developing countries, especially in emerging economies like Brazil, China, and India had a serious concern. Moreover, the effect is not evenly distributed. The poorest countries and people feel the adverse impacts of climate change first and will suffer the most from them as these countries are more vulnerable to the negative effects of rising sea level and the impact on water resources, ecosystems, crop production, fisheries, and human health [Akram, 2012].

Ethiopia is one the least developing country in the world, but recently Ethiopia had an impressive track of record growth and poverty reduction in recent years, with GDP growth averaging 10.1 percent in 2010/11-2014/15, about 8 percent GDP per capita growth. Poverty has declined markedly and inequality, with a Gini index of 30 percent, is low by international and Sub Saharan Africa (SSA) standards [International Monetary Fund, 2016]. However, Ethiopia is heavily dependent on rain-fed agriculture. The geographical location and topography coupled with low adaptive ability necessitate a high vulnerability to adverse impacts of climate change, due to these the country face drought in different periods due to climate changes that directly affecting the agricultural output [IMF, 2016]. This makes the country face different drought cause problems in different periods that lead to chronic food shortage and food insecurity for long periods [Gebreegziabher et al, 2011]. For instance, In 2015/16 El Niño drove climate change caused one of the worst droughts in many parts of Ethiopia this directly affect agricultural sector performance in that would affect other sectors of the economy [WB, 2010].

The vulnerability of agriculture production to climate change in Ethiopia have a direct effect on a rural population whose activity is producing agricultural products for their livelihoods and to generate income and it has an indirect effect on other sectors like industry sector those who use raw material from the agriculture sector and urban population through the increasing price of agricultural product. This would 


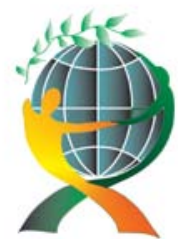

\author{
(online) = ISSN $2285-3642$ \\ ISSN-L = $2285-3642$ \\ Journal of Economic Development, Environment and People \\ Volume 9 , Issue 3, 2020 \\ URL: http://jedep.spiruharet.ro \\ e-mail: office jedep@spiruharet.ro
}

affect the economy of the country by affecting food security, water and energy supply, poverty reduction, and sustainable development efforts [NMA, 2007]. Climate changes in Ethiopia are occurring that affect directly the agricultural output of the country which depends on climate input.

Changes in the pattern of rainfall and temperature would affect the economy. Ethiopia recorded the lowest annual rainfall in 30 years in 2015 due to El Niño this would affect the economy where half of GDP comes from agriculture and $99 \%$ of electrical energy in a country on which industrial and service sector dependent is generated by hydroelectric power which in turn depends on the volume of rainfall [Ali, 2012]. A change in climate in Ethiopia may reduce the country's GDP by up to $10 \%$ by 2045 , mostly through influences on agricultural productivity, these changes also hamper economic activity and aggravate existing social and economic problems (United State Agency International Development, 2013).

Besides the importance of the agriculture sector, any shock related to climate change in the agriculture sector would have a wider economic impact on agriculture and other sectors. Previously research is conducted in this area, for instance, Tadele et al (2010) studied the impact of climate change on agriculture, Amsalu (2016) studies the economic wide effect of climate change, Deressa (2007) analyzed the impact of climate change on Ethiopian agriculture by Ricardian approach, world bank (2008) conducted economic impact of climate change and Ali (2012) analyzed the impact of climate change on economic growth. Most of those researches are used computable general equilibrium analysis which faces a limitation in that it doesn't consider the temporal effect of climate change on agriculture, Ricardaian approach is based on survey data on climate change so it may face valuation problem by respondents and require knowledge and the other examined impact of climate change on economic growth, but climate change directly affect agricultural production. To the researcher's knowledge, there is no evidence about the paper that relates climate change to single aggregate agricultural output that used time series analysis and the aim is to fill the gap and supplement the existing literature, and researching in this area is useful for national policies. So the study focuses on the effect of climate change on agricultural output in Ethiopia by using time series data that span from 1980-2016.

\title{
2. LITERATURE REVIEW
}

\subsection{Climate Change and Agriculture}

Climate can affect agriculture in a variety of ways. Temperature, radiation, rainfall, soil moisture changes in average temperatures; rainfall and climate extremes with an important impact on soil erosion, changes in pests and diseases, changes in atmospheric carbon dioxide, changes in the nutritional quality of some foods, changes in the growing season, and changes in sea level and carbon dioxide (CO2) concentration are all important variables to determine agricultural productivity, and their relationships are not simply linear [Zhai and Zhuang, 2009]. Current research confirms that there are thresholds for these climate variables above which crop yields decline. For example, the modeling studies discussed in recent IPCC reports indicate that moderate to medium increases in mean temperature (1-3으), along 


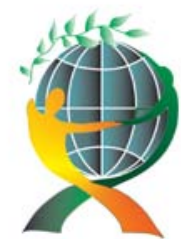

\author{
(online) = ISSN $2285-3642$ \\ ISSN-L = $2285-3642$ \\ Journal of Economic Development, Environment and People \\ Volume 9 , Issue 3, 2020 \\ URL: http://jedep.spiruharet.ro \\ e-mail: office jedep@spiruharet.ro
}

with associated $\mathrm{CO} 2$ increases and rainfall changes, are expected to benefit crop yields in temperate regions. However, in low-latitude regions, moderate temperature increases $\left(1-2^{\circ} \mathrm{C}\right)$ are likely to have negative yield impacts for major cereals. Warming of more than $3^{\circ} \mathrm{C}$ would have negative impacts in all regions [IPCC, 2007].

\title{
2.2. Contribution of Agriculture to the Economy of Ethiopia
}

Agriculture is known to supply the country with food grains, cash crops, and dairy and meat products among other things. Besides, the sector provides relatively abundant food and raw materials to the increasing industry-based urban population. Productivity in agriculture improves the level of income received by rural people. Increased income is believed to generate increased demand for manufactured goods from the industrial sector, also, to increase income improve the living standard, and take a part in the international market. Outside of gold, Ethiopia's top five exports are all agricultural products: coffee, sesame, fruits and vegetables, and leather. Thus, both domestically and internationally, agriculture remains at the heart of Ethiopia's development [ATA, 2016].

In reaching the middle-income country by 2025 agriculture sector plays a major contribution to the goal this through shifting smallholder farmers from subsistence-based production towards market orientation by modernizing tools and techniques is a primary objective for the sector. For long-term success, this shift must be done while simultaneously bolstering resilience toward climate change and ensuring environmental sustainability [ATA, 2016]. There is the year to year fluctuation in agricultural GDP this variation is due to climate change. So ignoring this sector would have a negative impact on economic growth.

\subsection{Empirical Literature On Impact Of Climate Change}

Barrios et al. (2007) examined the impact of climatic change on the level of total agricultural production of Sub-Sahara Africa (SSA) and non-SSA (NSSA) developing countries. The study utilized a new crosscountry panel climatic dataset in an agricultural production framework. The findings of the study revealed that climate change, measured as change in countrywide rainfall and temperature has been the major factor that influences agricultural production in SSA while in NSSA Countries agricultural production seems not to be affected by climate change.

Ogbuabor and Egwuchukwu (2017) conducted on the impact of climate change on the economy of Nigeria, by employing OLS method and error correction model. Time-series data variables like annual rainfall, carbon emission, and forest depletion are used to capture climate change and government expenditure, domestic private investment, the exchange rate was used as a control variable. They found that carbon emission affects growth adversely in the long run and short run, forest depletion impact negatively on growth in the short run. 


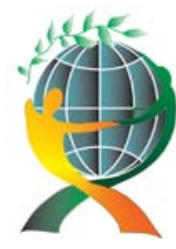

\author{
(online) = ISSN $2285-3642$ \\ ISSN-L = $2285-3642$ \\ Journal of Economic Development, Environment and People \\ Volume 9 , Issue 3, 2020 \\ URL: http://jedep.spiruharet.ro \\ e-mail: office jedep@spiruharet.ro
}

Akram (2016) study investigated the impacts of climate change on the economic growth of Pakistan by conducting a national level analysis for the period 1973-2011. He found that temperature (a proxy for climate change) has a negative and significant relationship with GDP, as well as with productivity in the agricultural, manufacturing, and services sectors. The severity of these negative effects is higher for the Agriculture sector as compared to manufacturing and services.

Alagided et al (2014) examine the effect of climate change on economic growth for 27 Sub-Saharan Africa countries including Ethiopia. They used the panel co-integration method. Temperature and precipitation are variables to capture climate change. There result reveals that a percentage increase in temperature significantly reduces economic performance in SSA by approximately $0.13 \%$ and they concluded that given sub-Saharan Africa relies on the agriculture sector for the majority of economic output, a higher temperature could actually reduce agricultural output.

Ali (2012), studies on the impact of climate change on rain-fed economy. He used annual rainfall, labor force, and land under major crops and co-integration method for analysis. He finds rainfall variation have a negative effect on growth.

As several empirical and theoretical reviews show climate variable like temperature, rainfall, soil moisture, deforestation, and land degradation affect economic growth through the effect on agricultural output as the empirical evidence shows, moreover rather than affecting economic growth it directly affects agricultural output which in turn affect livelihoods for the majority of people.

\title{
3. MODEL SPECIFICATION AND METHODOLOGY
}

\subsection{Data Description and Source}

Table 1 Summary of the data source by variable

\begin{tabular}{|l|l|l|}
\hline \multicolumn{1}{|c|}{ Type of variable } & \multicolumn{1}{c|}{ Unit/proxy } & \multicolumn{1}{c|}{ Source } \\
\hline Agriculture output & RAGDP & MOFeD \\
\hline Labor force & Total labor force(15-64)ages & CSA \\
\hline Agricultural land & \% of total land & WDI \\
\hline Temperature & Centigrade & CCKP \\
\hline Rainfall & Millimeter & CCKP \\
\hline Fertilizer input import & Metric ton & NBE \\
\hline
\end{tabular}

\subsection{Method of Data Analysis and Estimation Techniques Unit Root Test}

The reason for conducting a stationarity test is the use of non-stationary data can lead to spurious regressions. If the variables employed in a regression model are not stationary, then it can be proved that the standard assumptions for asymptotic analysis will not be valid. In other words, the usual'tratios' will not follow a t-distribution, and the F-statistic will not follow an F-distribution, and so on [Brooks, 2008]. 


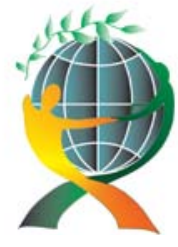

\author{
(online) $=$ ISSN $2285-3642$ \\ ISSN-L = $2285-3642$ \\ Journal of Economic Development, Environment and People \\ Volume 9 , Issue 3, 2020 \\ URL: http://jedep.spiruharet.ro \\ e-mail: office jedep@spiruharet.ro
}

To test unit root there are several varying approaches have been developed. Among the methods of testing the presence of a unit root in a series the common ones include Dickey-Fuller (DF), and Augmented Dickey Fuller (ADF), Based on DF test, the series $Y$ is stationary if the absolute value of ' $\delta$ ' in the equation is less than unity. However, it is not stationary if the absolute value of ' $\delta$ ' is greater than or equal to unity.

$$
\begin{gathered}
Y t=\delta Y t-1+U t \ldots \\
\Delta Y t=\alpha Y t-1+U t
\end{gathered}
$$

where, $\alpha=(1-\delta)$

Hence, the null that $\delta=1$ is equivalent to $H 0: \alpha=0$. However, DF test assumes that the data generating process follows the Auto Regressive of order one which biases the test in the presence of serial correlation. In order to calculate the critical values of the $\tau$ (tau) statistic, Dicky-Fuller assumes that the error terms (ut) are not correlated [Enders, 1996]. But the error term in the Dickey-Fuller test usually has autocorrelation, which needs to be removed if the result is to be valid. In addition, the critical values of $\tau$ (tau) statistics do not follow the normal distribution function and in general, the critical value is considerably larger than its counterpart of $\mathrm{t}$ - distribution. Therefore, using such critical values can lead to the over-rejection of the null hypothesis when it is true. The ADF unit root test is used to overcome this limitation of DF test. ADF overcome these limitations by adding additional lag of the first difference of the dependent variable. Therefore, this study used ADF test for stationary test.

Procedure for ADF test

$$
\Delta y t=a+\delta t+\gamma y t-1+\sum_{t=1}^{p} \mu \Delta y t-i+\epsilon t
$$

where $\delta$ is a time series variables under consideration in this model at time $\mathrm{t}$,

$\mathrm{t}$ - time trend variable

$\Delta$ - denotes the first difference operator

$\epsilon t$ - the error term; $p$ is the optimal lag length of each variable chosen such that first- differenced

terms make a white noise.

Thus, the ADF test is the null hypothesis of no unit root (stationary).

That is : $\mathrm{HO}: \gamma=0 \quad \mathrm{H} 1: \gamma \neq 0$ If the $\mathrm{t}$ value or t-statistic is more negative than the critical values, the null hypothesis (I.e. HO) is rejected and the conclusion is that the series is stationary. Conversely, if the tstatistic is less negative than the critical values, the null hypothesis is accepted and the conclusion is that the series is non-stationary.

\title{
3.3. Cointegration test
}

The term of co-integration was first introduced by Engle and Granger (1987) after the work of Granger and New bold (1974) on spurious regression. It identifies a situation where two or more non-stationary time series are bound together in such a way that they cannot deviate from some equilibrium in the long term. In other words, there exist one or more linear combinations of those I(1) time series (that is stationary (or I(0)). Those stationary combinations are called cointegrating equations. There are three major methods of testing co-integration: the Engel-Granger two-step procedure (EG), the Johansen Maximum Likelihood procedure, and ARDL bound test approach to co-integration. The Engle-Granger 


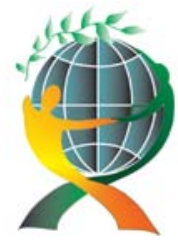

\author{
(online) = ISSN $2285-3642$ \\ ISSN-L = $2285-3642$ \\ Journal of Economic Development, Environment and People \\ Volume 9 , Issue 3, 2020 \\ URL: http://jedep.spiruharet.ro \\ e-mail: office jedep@spiruharet.ro
}

has its shortcomings these shortcomings are it is difficult to determine the number of equilibrium relationship if the variable is more than two since it allows for single co-integration and the Johansen cointegration approach method needs a variable to be integrated order of same whether I(0) or I(1) but not mix of the two. But, ARDL overcomes this problem.

ARDL Bound Test Approach To Co integration; A large number of past studies have used the Johansen co-integration technique to determine the long-term relationships between variables of interest. In fact, this remains the technique of choice for many researchers who argue that this is the most accurate method to apply for I(1) variables. Recently, however, a series of studies by Pesaran et al (1996) have introduced an alternative co-integration technique known as the Autoregressive Distributed Lag (ARDL) bound test. This technique has a number of advantages over Johansen co-integration techniques. First, the ARDL model is the more statistically significant approach to determine the co- integration relation in small samples. It can also lead us to know error correction model which can be derived from ARDL model through a simple linear transformation, which integrates short-run adjustments with long-run equilibrium without losing long-run information and error correction term shows how much of the disequilibrium is being corrected, that is, the extent to which any disequilibrium in the previous period is being adjusted in the year.

Model Specification and Theoretical Framework: The purpose of this study is to analyze the effect of climate change on agriculture output in Ethiopia. The study starts with the important work; the neoclassical growth model developed by Solow (1956). The neo-classical production function is specified in terms of traditional inputs like labor and capital. The following neoclassical production function was used. The advantage of this approach is that it controls explicitly for other inputs as indicated by (Deschenes and Greenstone 2004), However, its disadvantage lies in the fact that it does not take into account of the full range of compensatory responses to changes in climate made by farmers(Barrios et al 2007).

$$
Y t=f(L t K t)
$$

where $\mathrm{Yt}$ is aggregate real output, Lt is labor and kt is capital inputs

The model is specified as the following

$$
Y(t)=f(L, A T, M A R, F, A L)
$$

where RAGDP is real agricultural domestic growth product, $L$ labor force, AT Average temperature, MAR mean annual rainfall, $\mathrm{F}$ fertilizer input import, and AL Agricultural land.

Then converting to natural logarithm the model is :

$\log (R A G D P)=\beta o+\beta 1 \log (L F)+\beta 2 \log (A T)+\beta 3 \log (M A R)+\beta 5 \log (A L)+\beta 6 \log (F)+\varepsilon t$

where logRAGDP=natural logarithm of Real agricultural growth domestic product

Log LF=natural logarithm of labor force

LogAT = natural logarithm of Mean Annual temperature

LogAR = natural logarithm of Mean Annual rainfall

LogAL=natural logarithm of Agricultural land

Log F=natural logarithm of fertilizer input import 


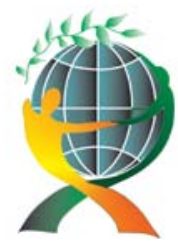

$$
\begin{gathered}
\text { (online) }=\text { ISSN } 2285-3642 \\
\text { ISSN-L }=2285-3642 \\
\text { Journal of Economic Development, Environment and People } \\
\text { Volume 9, Issue 3, } 2020
\end{gathered}
$$

URL: http://jedep.spiruharet.ro

e-mail: office jedep@spiruharet.ro

\begin{tabular}{|c|c|c|}
\hline Variable & Description & $\begin{array}{l}\text { Expected } \\
\text { sign }\end{array}$ \\
\hline Agricultural output & $\begin{array}{l}\text { total produce of the agricultural sector in the economy in a given } \\
\text { year }\end{array}$ & \\
\hline Labor force & $\begin{array}{l}\text { labor force (age from } 15-64 \text { years) a total number of labor force } \\
\text { that are economically active. }\end{array}$ & positive \\
\hline Average temperature & $\begin{array}{l}\text { is annual temperature is averaged over } 12 \text { months of } \\
\text { temperature that the country receive }\end{array}$ & negative \\
\hline Mean Annual rainfall & $\begin{array}{l}\text { rainfall that the country receives in } 12 \text { months taken as an } \\
\text { average over those months throughout the years }\end{array}$ & positive \\
\hline Agricultural land & $\begin{array}{l}\text { The share of land area that is arable, under permanent crops, and } \\
\text { under permanent pastures. }\end{array}$ & positive \\
\hline Fertilizer input import & $\begin{array}{l}\text { Fertilizer is the ingredient which increases the productivity of } \\
\text { agricultural products }\end{array}$ & positive \\
\hline
\end{tabular}

et=error term and $\beta 0$ are constant term while $\beta 1, \beta 2, \beta 3, \beta 4, \beta 5$, and $\beta 6$ are the parameter of independent variable to be estimated.

Tabel 2 Defintion of variable and Expected sign

\section{RESULT AND DISCUSSION}

\subsection{Unit Root Test Result}

Time series should be checked for stationary before conducting or estimating a model. To examine whether the data series under study is stationary at levels or stationary at differences the study employed ADF unit root test. Table 2. Augmented Dickey Fuller Unit root test results at the level and First difference 


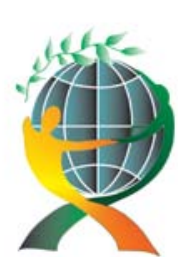

$$
\begin{gathered}
\text { (online) }=\text { ISSN 2285 - 3642 } \\
\text { ISSN-L }=2285-3642 \\
\text { Journal of Economic Development, Environment and People } \\
\text { Volume 9, Issue 3, } 2020
\end{gathered}
$$

URL: http://jedep.spiruharet.ro

e-mail: office_jedep@spiruharet.ro

\begin{tabular}{|l|l|l|l|l|l|}
\hline \multirow{2}{*}{ Variable } & \multicolumn{2}{|l|}{ With intercept and no trend } & With intercept and trend & \\
\cline { 2 - 6 } & At levels & First difference & At levels & $\begin{array}{l}\text { First } \\
\text { difference }\end{array}$ & $\begin{array}{l}\text { Order of } \\
\text { integration }\end{array}$ \\
\hline $\log ($ RAGDP) & 0.22919 & $9.264041^{* *}$ & $5.124627^{* * *}$ & $9.450906^{* * *}$ & $\mathrm{I}(1)$ \\
\hline $\log (\mathrm{MAR})$ & $4.993207^{* *}$ & $7.939576^{* * *}$ & $5.866566^{* * *}$ & $7.957953^{* *}$ & $\mathrm{I}(0)$ \\
\hline $\log (\mathrm{LF})$ & 0.751465 & $3.767619^{* *}$ & $3.767619^{* *}$ & $7.715934^{* * *}$ & $\mathrm{I}(1)$ \\
\hline $\log (\mathrm{FI})$ & 0.246291 & $10.98597^{* * *}$ & $4.405396^{* *}$ & $11.11200^{* * *}$ & $\mathrm{I}(1)$ \\
\hline $\log (\mathrm{AL})$ & 1.58964 & $5.488356^{* * *}$ & 0.952445 & $5.686601^{* * *}$ & $\mathrm{I}(1)$ \\
\hline $\log (\mathrm{AT})$ & $2.6790818^{*}$ & $5.953295^{* *}$ & $3.32928^{*}$ & $5.877539^{* *}$ & $\mathrm{I}(0)$ \\
\hline
\end{tabular}

Source: author calculation, 2018

Notes: The rejection of the null hypothesis is based on MacKinnon (1996) critical values Null hypothesis: series has unit root. ${ }^{*}$ Rejection at $1 \%$ level. ${ }^{* *}$ Rejection at $10 \%$ \& $\%$ and ${ }^{* * *}$ Rejection at (1\%, 5\% \& $\left.10 \%\right)$ level.

\subsection{Selecting Optimal Lag Length}

It is critical to choose the order of the model that yields a good model and hence precise forecast. The order of the VAR model refers to the optimal number of lags that should be included in the model. Different types of lag selection criteria are there For the selection of the lag order, there are, which includes the sequential modified likelihood ratio (LR), Akaike information criteria (AIC), Final prediction error (FPE),Schwarz information criterion(SC) and Hannan-Quinn information criterion (HQIC). The following table shows the lag length chosen by different information criteria.

Table 3: Results of lag order selection criteria

\begin{tabular}{|l|l|l|l|l|l|l|}
\hline Lag & logL & LR & FPE & AIC & SC & HQ \\
\hline 0 & 142.3707 & NA & $1.32 \mathrm{e}-11$ & -8.021806 & -7.752445 & -7.129947 \\
\hline 1 & 270.639 & 201.7089 & $6.02 \mathrm{e}-14$ & -13.44893 & $-11.56343^{*}$ & -12.80592 \\
\hline 2 & 324.2405 & $66.2248^{*}$ & $2.64 \mathrm{e}-14$ & -14.48474 & -10.98309 & -13.29057 \\
\hline 3 & 381.7345 & 50.72994 & $1.39 \mathrm{e}-14$ & 15.74956 & -10.63129 & -14.00377 \\
\hline
\end{tabular}

Source; author calculation, 2018 *indicates the lag length selected by the criteria

\subsection{ARDL Bound Test To Co Integration Result}

By using Automatic selection lag length criteria for the model bound test is applied so as to identify the presence of long-run relationship among the variables included in the model and test is as displayed here. 


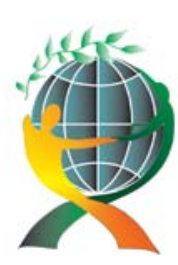

\author{
(online) = ISSN $2285-3642$ \\ ISSN-L = $2285-3642$ \\ Journal of Economic Development, Environment and People \\ Volume 9 , Issue 3, 2020
}

URL: http://jedep.spiruharet.ro

e-mail: office jedep@spiruharet.ro

Table 4. Result of Bound Test

\begin{tabular}{|l|l|l|}
\hline Variable & F-statistics & Co integration \\
\hline F(RAGDP, LF, MAR, FI,AL,AT) & $9.686542^{* * *}$ & Co integration \\
& & \\
\hline Critical value & Lower bound & Upper bound \\
\hline $1 \%$ & 3.41 & 4.68 \\
\hline $5 \%$ & 2.62 & 3.79 \\
\hline $10 \%$ & 2.26 & 3.35 \\
\hline
\end{tabular}

Source: author calculation, 2018

*** rejection of null hypothesis no co integration at $1 \%, 5 \%$, and $10 \%$ significance level.

The table reveals that F-statistics 9.686542 which exceeds the upper bound at $1 \%, 5 \%$, and $10 \%$ critical value and this implies there is a long-run relationship among variables in the model.

\title{
4.4.Estimation of Long-Run Model Result
}

Table 5. Estimation of long run model ARDL result Dependent variable is log(RAGDP)

\begin{tabular}{|c|c|c|c|c|}
\hline Variable & Coefficient & Standard error & t-statistics & p-value \\
\hline Log(MAR) & 0.5675 & 0.159450 & 3.559667 & $0.0014 * *$ \\
\hline $\log (\mathrm{AT})$ & -2.56001 & 0.663537 & -3.858147 & $0.0006 * *$ \\
\hline Log(LF) & 0.959257 & 0.125867 & 7.621193 & $0.0000 * * *$ \\
\hline $\log (A L)$ & 0.313009 & 0.091934 & 3.404700 & $0.0021 * * *$ \\
\hline $\log (\mathrm{FI})$ & 0.202502 & 0.043884 & 4.614436 & $0.0001 * * *$ \\
\hline Constant & 9.215554 & 2.071634 & 4.4484470 & $0.0000 * * *$ \\
\hline
\end{tabular}

Effect of Mean Annual Rainfall on Agricultural Output; since the formulated econometric equation is in log-log form, the coefficients are interpreted as elasticity or responsiveness of change. The findings in table 5. reveal that mean annual rainfall has a positive and significant effect on agricultural output measured by RAGDP. The result indicating that a 1 percent increase in mean annual rainfall increases agricultural output by 0.56 percent or $1 \mathrm{~mm}$ increase or change in rainfall leads to an increase of RAGDP by $0.56 \%$ in the long run. This result suggests that rainfall is the most important in determining agricultural output which is the major contributor to economic growth and it is consistent with the result by Barrios, et al (2007) in Sub Saharan Africa they found that if rainfall is declining it would reduce agricultural output and if rainfall increase agricultural output would be an increase in SSA. This shows rainfall is a major factor that determines agricultural output in SSA. Rainfall in Ethiopia is a major input in determining output due to this the country is named as rain-fed economy, where rainfall plays an 


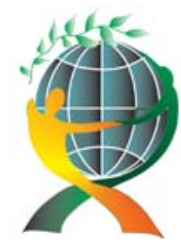

\author{
(online) = ISSN $2285-3642$ \\ ISSN-L = $2285-3642$ \\ Journal of Economic Development, Environment and People \\ Volume 9 , Issue 3, 2020 \\ URL: http://jedep.spiruharet.ro \\ e-mail: office jedep@spiruharet.ro
}

important role. In addition, this result is going in line with Wanjiru and Ruigu (2017) where they found that rainfall affect positively and significant relationship with agricultural productivity in the long run.

effect of Temperature on Agricultural Output; the results indicate that average temperature have a negative impact on agricultural output and significantly reduces agricultural output. A one percent increase in average temperature would reduce agricultural output by $2.5 \%$ in the long run. The long-run elasticity of agricultural output with respect to average temperature is -2.5 indicating that agricultural output is most sensitive to an increase in average temperature, in the long-run, this due to an increase in temperature change will likely result in decreasing agricultural productivity. This may be that high temperature depletes soil nutrients making it hard on livestock and agricultural output generally. In the long-run increase in temperature reduces soil moisture that negatively affects crop production which reduces agricultural output. In the short term temperature increase may increase crop productivity and others output, but in long term result in heat stress, reduction of water, reduction of feed resources livestock, and agriculture production failure that leads to a reduction of agricultural output which directly affect country economy generally and rural and urban population particularly through the increasing price of agricultural output for the urban population.

Effect of Labor Force on Agricultural Output; as the agricultural sector absorbs a major part of labor force contributing around $72.7 \%$ of employment in the economy. In the long run, the effect labor force on agricultural output is positive and significant at all levels. In the long run, there would be a change in the occupation of labor from traditional to educated labor that produces more output in the agriculture sector. This would cause the agricultural output to be positively affected by labor force. And it goes in the same direction with agricultural output. A 1 percent increase in labor force would result in an increase of agricultural output by $0.95 \%$ percent and its significance at all levels.

Effect of Fertilizer Input Import on Agricultural Output; Fertilizer is the main input in the agriculture sector especially for crop production that would increase agricultural output. As the table shows it has positive effect on agricultural output as it increases agricultural output and it has a significant effect on it. A 1 percent increase in fertilizer input import would lead to a $0.20 \%$ increase in agricultural output. An increase in the fertilizer import over a period increases the output. An increase in the fertilizer input import which means an increase of in its consumption in other words increases the output of crop production particularly and increases agricultural output generally. An increase in agricultural output leads to an increase of overall GDP and improve the living standard of the rural population whose livelihoods are dependent on agriculture. If there is an increase in the agricultural output it increases the export of the country which leads to the gain of foreign exchange to the country. This result is similar to Samuel (2012) who used fertilizer input import as a control variable and he found a positive and significant effect on agricultural export through an effect on agricultural output.

Effect of Agricultural Land on Agricultural output; The long-run result indicates that $1 \%$ increase in agricultural land leads to $0.31 \%$ increase in agricultural output since agricultural land plays an important role in determining agricultural output where there is an increase in agricultural land there would be an increase in output and it has a significant effect on agricultural output that increases the gross domestic product in general. 


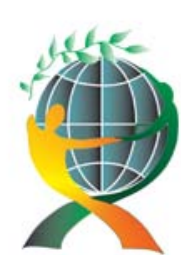

\author{
(online) = ISSN $2285-3642$ \\ ISSN-L = $2285-3642$ \\ Journal of Economic Development, Environment and People \\ Volume 9 , Issue 3, 2020
}

URL: http://jedep.spiruharet.ro

e-mail: office jedep@spiruharet.ro

\title{
4.5. Error Correction Representation of ARDL Result
}

Table 6 Error Correction Result Dependent variable is LD (RAGDP)

\begin{tabular}{|l|l|l|l|l|}
\hline Variable & Coefficient & Standard error & T statistics & P value \\
\hline LD(MAR) & 0.419322 & 0.121361 & 3.455157 & $0.0018^{* *}$ \\
\hline $\mathrm{LD}(\mathrm{LF})$ & 0.708676 & 0.093313 & 7.594582 & $0.0000^{* *}$ \\
\hline $\mathrm{LD}(\mathrm{FI})$ & 0.057706 & 0.027364 & 2.10889 & 0.0444 \\
\hline $\mathrm{LD}(\mathrm{AT})$ & -0.048664 & 0.459323 & -0.105947 & 0.9164 \\
\hline $\mathrm{LD}(\mathrm{AL})$ & 0.231243 & 0.067514 & 3.425102 & $0.0020^{* *}$ \\
\hline $\mathrm{ECT}-1$ & -0.738778 & 0.070093 & -10.539989 & $0.0000^{* *}$ \\
\hline
\end{tabular}

$L$ - is refers to logarithm $D$-lagged difference. ${ }^{*},{ }^{* *}$ and ${ }^{* * *}$ indicate significance at the 10, 5 and 1 percent levels.

The short-run result shows that last year's mean annual rainfall has a positive and significant impact on agricultural output while last year's temperature has negatively affected agricultural output but it has an insignificant effect on agricultural output. Whereas other variables have a positive impact on agricultural output. The error correction terms represent the speed of adjustment towards the long-run equilibrium. This coefficient term indicates that $73.8 \%$ of the disequilibrium in the previous period is corrected in one year.

\subsection{Diagnostic test result}

\begin{tabular}{|c|c|c|c|c|}
\hline & \multicolumn{2}{|l|}{ LM version } & \multicolumn{2}{|l|}{ F-version } \\
\hline Test & Statistic & P-value & Statistic & P-value \\
\hline Normality: Jarque-Bera test & $x^{2}(2) 0.07865$ & 0.89966 & not applicable & \\
\hline \multicolumn{5}{|c|}{ Serial Correlation: Breusch-Godfrey serial correlation } \\
\hline $\begin{array}{l}\text { LM } \\
\text { test }\end{array}$ & $x^{2}(2) 14.8009$ & 0.0006 & 0.012172 & 0.9130 \\
\hline Heteroskedasticity: Breusch-Godfrey test & $x^{2}(2) 13.79060$ & 0.0721 & $F(1,28) 0.0721$ & 2.09567 \\
\hline Ramsey RESET test & $x^{2}(26) 0.56478$ & 0.3682 & $F(1,26) 0.016516$ & 0.8987 \\
\hline
\end{tabular}

\section{Model stability}

In addition to the above diagnostic tests, the stability of long-run estimates has been tested by applying the cumulative sum of recursive residuals (CUSUM) and the cumulative sum of squares of recursive residuals (CUSUMSQ) test. Since the test statistics of these stability tests can be graphed, we can identify not only their significance but also at what point of time a possible instability (structural break) occurred. If the plot of CUSUM and CUSUMSQ statistic moves between the critical bounds (at $5 \%$ significance level), then the estimated coefficients are said to be stable. 

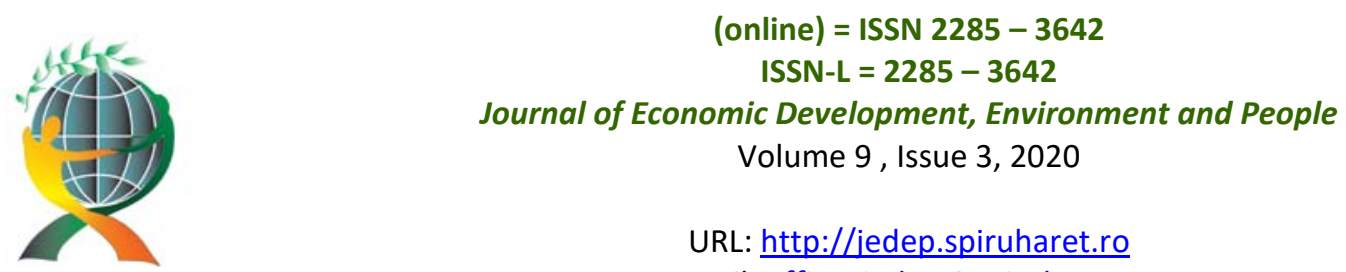

URL: http://jedep.spiruharet.ro

e-mail: office jedep@spiruharet.ro

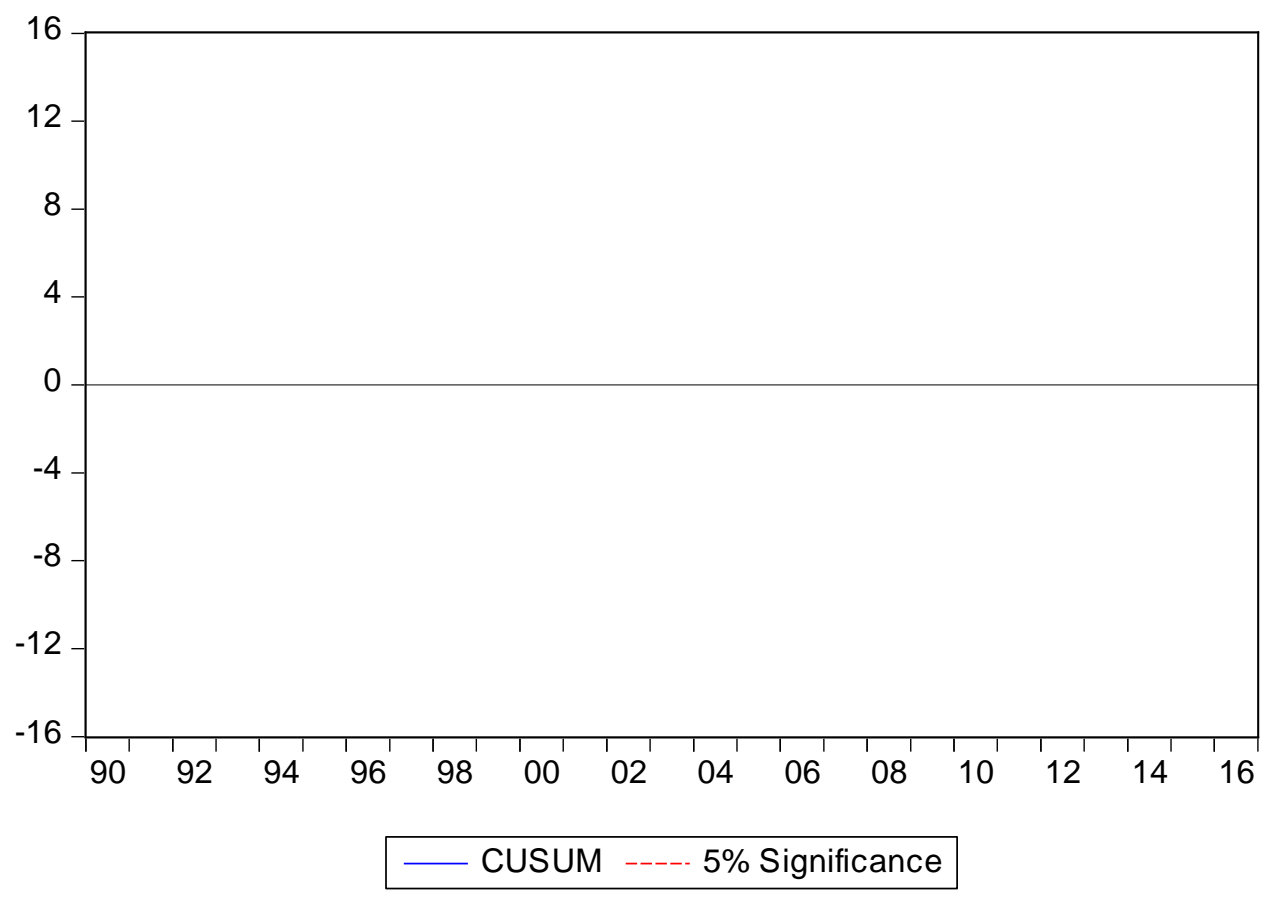

Figure 1. Plot of cumulative sum of recursive residuals

(Source: Author Calculations.

Note: The straight lines represent critical bounds at 5\% significance level)

The results of both CUSUM and CUSUMSQ test are reported in Figures 1 and 2. As can be seen from the first figure, the plot of CUSUM test did not cross the critical limits. Similarly, the CUSUMSQ test shows that the graphs do not cross the lower and upper critical limits. So, we can conclude that long and short runs estimates are stable and there is no any structural break. Hence the results of the estimated model are reliable and efficient. 


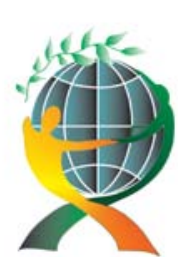

$$
\begin{gathered}
\text { (online) }=\text { ISSN 2285-3642 } \\
\text { ISSN-L }=2285-3642 \\
\text { Journal of Economic Development, Environment and People } \\
\text { Volume 9, Issue 3, } 2020
\end{gathered}
$$

URL: http://jedep.spiruharet.ro

e-mail: office jedep@spiruharet.ro

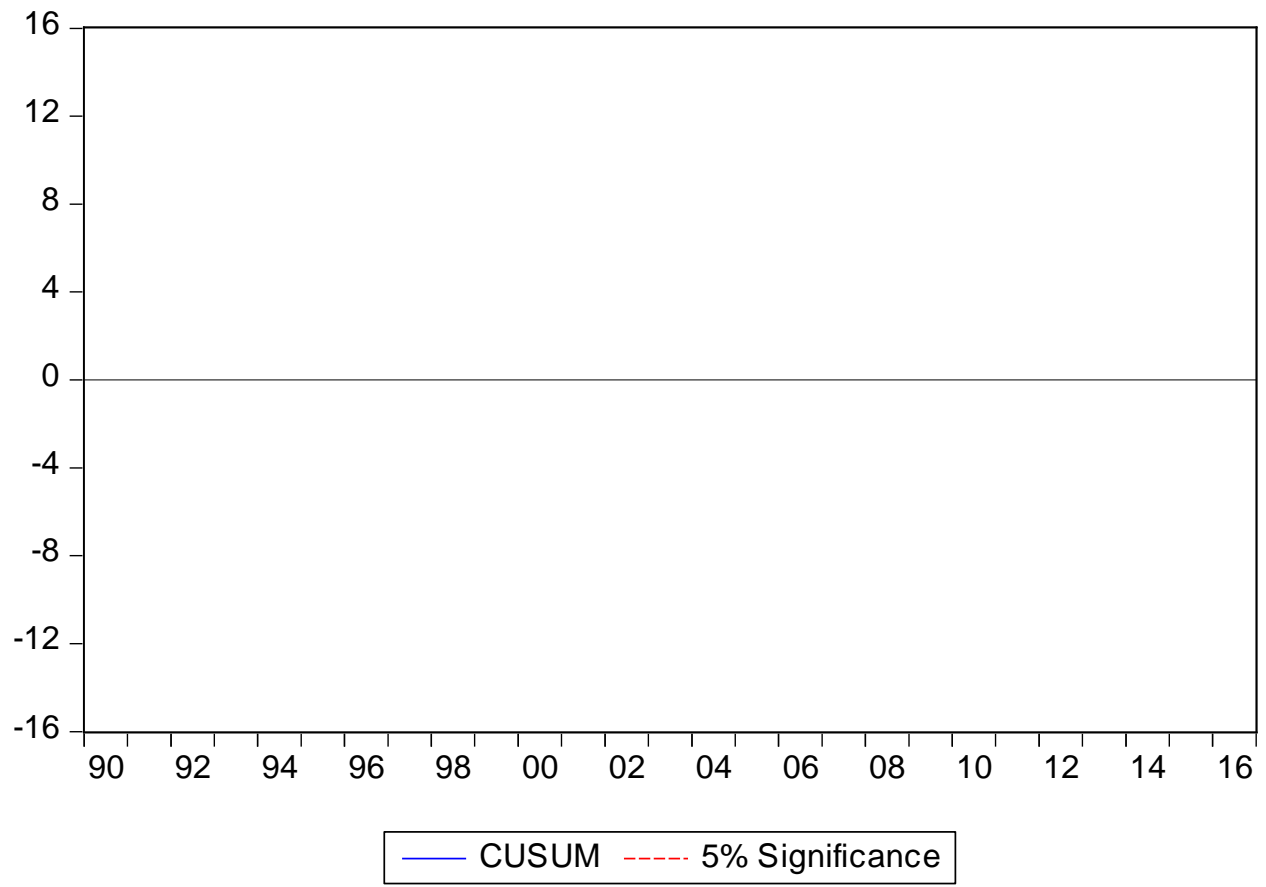

Fig 2. Plot of the cumulative sum of squares of recursive residuals

(Source: Author Calculations.

Note: The straight lines represent critical bounds at $5 \%$ significance level)

\section{CONCLUSIONS AND RECOMMENDATIONS}

The main objective of the study was to analyze the effect of climate change on agricultural output in Ethiopia using the real agricultural gross domestic product as a proxy for agricultural output. The study used ARDL approach to co-integration. The main finding of this study is that in the long-run climate change proxied by mean annual rainfall and the average temperature has an impact on agricultural output. In the long-run mean annual rainfall has a positive and significant effect on agricultural output, whereas average temperatures have a negative and significant effect on agriculture output. In other words, holding other things remaining constant one percent increase in mean annual rainfall has resulted in $0.56 \%$ RAGDP in the long run, however, one percent increase in temperature has resulted from $2.56 \%$ reduction of RAGDP. In the short run coefficient of error correction -0.738 suggesting about $73.8 \%$ annual adjustment towards long-run equilibrium. This shows there is the existence of a stable long-run relationship among variables. The estimated short-run reveals that rainfall has a positive impact on agricultural output, whereas average temperatures have a negative impact on agricultural output but, unlike its long-run significant impact temperatures have no significant short-run impact on agricultural output. In order to reduce effect of climate change in the long run and short run mitigation 


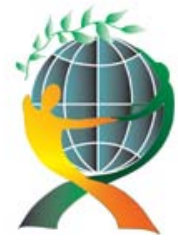

\author{
(online) = ISSN $2285-3642$ \\ ISSN-L = $2285-3642$ \\ Journal of Economic Development, Environment and People \\ Volume 9 , Issue 3, 2020 \\ URL: http://jedep.spiruharet.ro \\ e-mail: office jedep@spiruharet.ro
}

and adaptation strategies should be in place. Adaptation strategies may focus on the option of producing or water harvesting as it rains instead of waiting for the traditional seasons of agricultural activities. Adaptation is important in the long-run whereas mitigation plays an important role in the short-run. In addition to this government, and other stakeholders should make agriculture sector climate change resilient by using different technology and providing sufficient and timely information for farmers on climate forecast both at the macro and micro levels. And reduce dependence on rainfall economy through diversifying the economy to climate-resistant sector.

\title{
References
}

[1] Akram Neam (2016) Climate change: A threat to the economic growth of Pakistan, Ministry of Economic Affairs, Islamabad, Pakistan

[2] Amsalu W. Yalew(2016) Economy-wide Effects of Climate Change in Ethiopia

[3] Agricultural Transformation Agency (ATA). (2016), annual report Addis Ababa, Ethiopia

[4] Barrios S, Strol E, and Ouattra B(2007) The Impact of Climatic Change on Agricultural Production: Is it different for Africa? Food Policy, 33(4), p. 287-298

[5] Brooks, C. (2008). Introductory Econometrics for Finance. Cambridge, Cambridge University Press

[6] Deschenes, O., \& Greenstone, M. 2004. The Economic Impacts of Climate Change: Evidence from Agricultural Profits and Random. NBER Working Paper Series No. 10663. Cambridge: National Bureau of Economic Research

[7] Enders ,W.(1996). Applied Econometric Time Series. Lowa State University: John Wiley \&Sons INC

[8] Engle, R. F. and Granger, C.W.J. (1987). Co-integration and Error Corrections: Representation, Estimation and Testing. Econometrica, 55(2), 251-276

[9] Ferede T, Ayenew B and. Hanjra A(2010) AGroecology Matters: Impacts Of Climate Change On Agriculture And Its Implications For Food Security In Ethiopia

[10] Gebreegziabher, Z., Stage, J., Mekonnen, A., and Atlaw, A. (2011). Climate Change and the Ethiopian Economy: A Computable General Equilibrium Analysis. EfD DP 11-09. Discussion Paper Series. Environment for Development Initiative

[11] Granger, C. W. J. and Newbold, P. (1974). Spurious Regressions in Econometrics. Journal of Econometrics, 2, 111-120

[12] International Monetary Fund (IMF). (2016) country report of Ethiopia

[13] Intergovernmental Panel on Climate Change (IPCC) (2014) Climate change report adaption, impact and vulnerability regional aspects

[14] Intergovernmental Panel on Climate Change (IPCC) (2007) climate change synthesis report Geneva, Switzerland

[15] Jonathan E. Ogbuabor and, Emmanuel I. Egwuchukwu (2011) The Impact of Climate Change on the Nigerian Economy, International Journal of Energy Economics and Policy ISSN: 2146-4553 available at http: www.econjournals.com, International Journal of Energy Economics and Policy, 2017, 7(2), 217-223. 


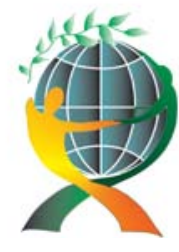

\author{
(online) $=$ ISSN $2285-3642$ \\ ISSN-L = $2285-3642$ \\ Journal of Economic Development, Environment and People \\ Volume 9 , Issue 3, 2020 \\ URL: http://jedep.spiruharet.ro \\ e-mail: office jedep@spiruharet.ro
}

[16] Naeem Akram, (2007) is climate change hindering economic growth of Asian economies?

[17] National Meteorological Agency (NMA). (2007), "Climate Change National Adaptation Program of Action (NAPA) of Ethiopia," NMS, Addis Ababa, Ethiopia

[18] Paul Alagidede, George Adu, And Prince And Boakye Frimpong ( 2014) The Effect Of Climate Change On Economic Growth Evidence From Sub-Saharan Africa Wider Working Paper

[19] Pesaran, M. H. a. Smith. (1998). "structural analysis of co-integration VARS." Journal of economic surveys 12(5): 471-505

[20] Pesaran M.H, R.J. Smith, and Y. Shin,(1996) Testing for the Existence of a long run Relationship, DAE Working paper No.9622, Department of Applied Economics, University of Cambridge,

[21] Samuel Tekste (2012) determinants of agricultural export performance in Ethiopia

[22] Seid Nuru Ali (2012) Climate Change and Economic Growth in a Rain-fed Economy: How Much Does Rainfall Variability Cost Ethiopia? Ethiopian Economics Association Working Paper Series. Addis Ababa, Ethiopia.

[23] Solow, R. (1956). A Contribution to the Theory of Economic Growth. Quarterly Journal of Economics, 70(1), 65-94

[24] Temesgen Tadesse Deressa, 2007 Measuring The Economic Impact Of Climate Change On Ethiopian Agriculture: Ricardian Approach, Policy Research Working Paper

[25] United States Agency for International Development,(USAID), (2013) Ethiopia vulnerability climate profile

[26] Wanjiru and Ruigu (2017) determinants of agricultural productivity in Kenya, international journal of economics, commerce and management vol. $\mathrm{V}$

[27] WB (World Bank) 2008 A Country Study on the Economic Impacts of Climate Change Ethiopia

[28] Zhai, F. and Zhuang, J. (2009), "Agricultural Impact of Climate Change: A General Equilibrium Analysis with Special Reference to Southeast Asia" 